Research Article

Open Access

Dovilè Jankauskaitė

\title{
Social Media as a Tool for Improving Teaching and Learning Experience
}

DOI 10.1515/sigtem-2016-0008

\begin{abstract}
At least a quarter of human population is actively engaging in social media. Social media possesses a high level of influence and importance. For example, social media shapes communication habits between people and provides a communication channel for business enterprises. The statement that teachers should utilise social media as a tool for improving teaching and learning experience, rather than ignoring it, is becoming a common topic for discussion. Hence the aim of this article is to analyse how to use social media in order to improve teaching and learning experience. A theoretical overview of scientific literature on the topic of social media application prospects in education is provided in this article, and a traditional input-process-output schematic for social media usage in teaching and learning is also developed.
\end{abstract}

Keywords: social media, social networks, engagement, teaching and learning.

\section{Introduction}

Social media's influence on contemporary, technology-based society is undeniable. It is a phenomenon that changes the communication habits of people, creates opportunities for business, provides publicity for various organisations and individuals, encourages sharing of information and affects life in other ways. In late 1970s, along with the advent of Internet, an idea that connected computers turning the network into a great forum for discussing mutual topics of interest, was born. Later on, this idea was developed, and Web 2.0 technology was created as a result.

Social media emerged as a result of Web 2.0. According to Toplu et al. $(2014,30)$, 'its characteristics include interpersonal communication, information sharing and a user-focused design', and it is exactly the interpersonal communication and information sharing that make up the base of social media. Social media, most commonly defined by the following definition by Kaplan and Haenlein (2010, 61), is 'a group of Internet-based applications that build on the ideological and technological foundations of Web 2.0, and that allows the creation and exchange of user-generated content'.

Social media can be used as a tool for education - personal learning environment (Dabbagh et al, 2012), open distance education (Kulakli et al, 2014), improving teaching and learning experience (Bexheti et al, 2014; Dear et al, 2014; Danciu et al, 2011; Milosevic et al, 2015; Oberer et al, 2012; Popoiu et al, 2012; Rasiah, 2014; Thomas et al, 2012; Wagner, 2011) or others. Hence social media has an undeniable influence on education and is a tool for improving teaching and learning experience.

\section{The Aim of the Study}

The aim of this study is to analyse how to use social media in order to improve teaching and learning experience by creating a traditional input-process-output schematic for social media usage in teaching and learning.

*Corresponding author: Dovilè Jankauskaitè: Dovilè Jankauskaitė, Vilnius University, Gediminas str. 20 - 16, Kaišiadorys, Lithuania, E-mail: jankauskaitedovile9@gmail.com 


\section{Materials and Methods}

Social media is a fairly expansive subject that covers (1) social networking (e.g. LinkedIn, Twitter), (2) content production (e.g. Wikipedia), (3) video and photo sharing services (e.g. YouTube), (4) virtual worlds (e.g. Second Life) and (5) diary-type webs (blogs) (Aula, 2010). Kapoor et al. (2013) also added 'virtual game worlds' (e.g. World of war craft). Hence social media possesses various services that can be used in various ways for improving teaching and learning experience. According to Kietzmann et al. (2011), different social activities have different functional traits: identity, conversations, sharing, presence, relationships, reputation and groups. Specific social media sites can possess different traits (e.g. YouTube is mainly about sharing, but as important are the conversations and presence). According to these properties, it can be shown how social media and its respective qualities can be used for improving teaching and learning experience (see Table 1).

Table 1. Social media functions for improving teaching and learning experience

\begin{tabular}{lll}
\hline Functional trait: & Improving teaching experience: & Improving learning experience: \\
\hline Identity & $\begin{array}{l}\text { To develop the identity of the subject } \\
\text { To develop teachers identity and share it with the } \\
\text { students }\end{array}$ & $\begin{array}{l}\text { The understanding of the subject is established } \\
\text { Helps to develop students identity and share it with } \\
\text { the teacher and other students }\end{array}$ \\
& To understand student identities & To understand teacher identity \\
Conversations & Having two-way communication & Having two-way communication \\
& Getting feedback & Getting feedback
\end{tabular}

Firstly, social media 'enables the student and teacher to build a clear, much more convenient and interactive relationship' - identities of subject, teacher and students are developed, discussions are carried out, all kinds of content are being shared, there are no time or location constraints (Thomas et al, 2012, 364). Due to the fact that social media is accessible to mostly everyone, at any time at any place, teachers and students quickly and easily receive information, which improves transparency. The teacher or the student can explain their decisions to everyone (McLeod, 2014), can carry out surveys, provide additional information, which may have reduced or omitted completely due to time constraints during lectures.

Social media may help managing schedules and making announcements - 'send out reminders, upcoming, events and schedule changes', which will be seen by students at the times appropriate to them (Wagner, 2011, 51). There are various other features, which may improve the teaching and learning experience, for example teachers and students can use hashtags (\#) to identify topics. Wagner (2011) gives an example - if you are posting a tweet related to athletic training education programmes, you may use hashtag \#ateps, so the search on the \#ateps will reveal all tweets tagged with \#ateps.

However, social media can have negative influence on teaching and learning. First of all, it is important to not forget that social media 'represents an "anything goes" communication channel' (Voloaca et al, 2011, 450). Therefore it is important to choose the content, which would not intrude on ethical norms and would use correct language. This is especially true when using hashtags that the teacher must constantly 
observe and follow news on the hashtag in use, so that inappropriate content would not reach students. Teachers are taken out of their 'comfort zones', and they must not only be acquainted with the social media itself, use it professionally but also to create and manage unique participation between the teacher and the student (Popoiu et. al, 2012). Also, 'nothing is private on the internet and that the internet has a very, very long memory'. All social media sites possess various fine functions, which can be used for improving teaching and learning experience; however, due to their overwhelming quantity, teacher or student can unknowingly share private content (Dear, Potts, 2014, 33). A traditional input-process-output schematic, which reveals social media usage process for teaching and learning (see Table 2), is provided.

Table 2. Social media usage process for teaching and learning

\begin{tabular}{llll}
\hline & Input & Process & Output \\
\hline Teaching & 1. Acquaintance with social media & 1. Content creation and Improved teaching expe- \\
& 2. Adjustment of teaching material to fit the social media & sharing & (Table 1, second \\
& 3. Plan how to use social media & 2. Engagement & column) \\
& 4. Social media policy & & \\
& 5. Creation of social media accounts & & Improved learning \\
Learning & 1. Acquaintance with social media & & $\begin{array}{l}\text { experience (Table 1, third } \\
\text { column) }\end{array}$ \\
\hline
\end{tabular}

Before beginning to use social media for teaching and learning, it is essential to get acquainted with social media tools and their application capabilities. In such a case, the teacher is not only a professional of his field, but also a social media expert. For the teacher, it is important not only to get acquainted with social media tools and their capabilities overall, but to understand applicability of respective social media tools in the field as well, which would be presented to the students. Birgit Oberer and Alptekin Erkollar (2012) presented their practice, where they prepared a 'Geographic Marketing' course with Google Plus integration. This course gained a lot of attention and active participation from students in comparison with 'Introduction to Marketing' or 'Geographic Information Systems' courses. Hence, Google Plus and its capabilities were successfully applied during the lectures.

How can other social media services be used?

1. Social networking - can provide tools to build communities, a platform for two-way communication. For example, while teaching advertising management, I constantly communicate with students through Facebook. Students themselves express the wish to communicate not through university system or e-mail, because they use Facebook in their daily life and would see my messages sooner. This way we create Facebook study group, where we discuss news, share ideas, ask questions and communicate.

2. Content production services like Wikis can be used as social software for sharing knowledge, team working, collaborative writing or making small projects.

3. Video and photo sharing services (this category can include slide sharing or audio sharing as well) - teacher can provide different types of content about the subject, and that way information would be in a visually interesting format. Using different formats can be more appealing to students and can better reflect a particular situation. According to Popoiu et al. (2012), John Hopkins Hospitals is using video clips to explain birth.

4. Virtual worlds - simulation of real world online: This service can be used in the learning process to conduct research or as a communication platform. Popoiu et al. (2012) gives an example of how medical librarians have created libraries in Second Life, and offer simulated reference services through avatars.

5. Diary-type webs (blogs) - can be easily used as a teaching or learning tool. Both the teacher and the student can create blogs about the subject. They can also follow blogs of professionals from particular fields, projects and other useful teaching and learning blogs. 


\section{Results}

As can be seen from a few examples, social media has various services, which can be used for improving teaching and learning experience. However, just ideas how to use social media features are not enough. A clear plan on what, where and how social media tools can be applied must be developed.

Another important item before beginning to use social media for teaching and learning is social media policy. As mentioned before, social media is a space where any kind of information can be stored and incorrect language can be used. Therefore an agreement is necessary on following ethical boundaries, usage of correct language and other aspects of social media usage. When discussing social media policy, it is important not only to set the rules for behavior during the time of learning, but also to explain how students should represent their selves in their private social media accounts.

Also, when preparing social media policy, the issue of privacy arises. Both the teacher and the students do not want to share all of their accounts/data with each other (Popuiu et al, 2012). Also in some universities or schools, adding students as a 'friend' on social media sites is not allowed or undesired, because 'that is mainly because there is a mixture between the private sphere and school's sphere' (Oberer et al, 2012, 1891). If such practice is forbidden, both teacher and students should create 'throw-away accounts', which are special accounts for the class (Dear, Potts, 2014). Hence after completion of the course, the account and data would be erased. Another issue that may arise when creating accounts for social media is the usage of other people's names and surnames. If for some reason the teacher or students do not want to use their real names, it would be preferable to establish a specific name by which only teacher and students could identify each other (Popuiu et al, 2012).

Process of social media usage for teaching and learning consists of (a) content creation and sharing and (2) engagement. Social media uses these types of content - text, image, video, audio or games (Ouirdi et al, 2014). Both teacher and students can create content and share it with others, or just share already created content. After sharing content, others can comment, share or in other ways use the provided content, in turn generating user content (e.g. memes). User-generated content (UGC) is 'any form of content such as blogs, wikis, discussion forums, posts, chats, tweets, podcasting, pins, digital images, video, audio files, and other forms of media that was created by users of an online system or service, often made available via social media networks' (Moens et al, 2014, 7). It is exactly during the periods of teaching and learning that parties of interest create and share UGC, with others. For example, in the advertising management course, students are constantly challenged to create ads, so they create video clips, which are hosted on YouTube, then the effectiveness of the advertisement is gauged by the viewer feedback. When talking about social media and content, it is important to take note of and not to intrude on intellectual property rights, even for educational purposes.

According to Dijkmans et al. (2015), the term 'engagement' is defined in terms of a combination of cognitive aspects (e.g. being interested), behavioral aspects (e.g. participation) and/or emotional aspects (e.g. feeling positive). Hence, both the teacher and students should engage in learning via social media comment, give feedback, discuss, give questions or in other way engage. Most researchers and practitioners make note on the importance of social media engagement. However, engagement in social media takes a lot of time, because social media must be constantly monitored. Therefore, it is necessary to 'frequently check sites and respond'(McEachern, 2011, 448). Most students use different social media networks in their daily life and are well enough acquainted with most functions; however, most teachers do not use social media as much, and therefore they find engagement in it as a waste of time. According to the results of study by Bexheti et al (2014) in 2011 65\% teachers stated that they do not use social media while teaching because it takes too much time to learn. Despite such results, a lot of teachers, when asked about potential of social media „for positive change in education, more than $70 \%$ of the teachers answer agree or strongly agree“ (Bexheti et al, 2014, 93).

So to sum up, suggestions by Dear and Potts (2014) on how to engage social media in teaching process are provided: 1 . Get familiar enough with the tool; 2 . Actively maintain and own presence across multiple digital spaces; 3. Teach students how to curate their online presence; 4. Design exercises that emphasize 
practice, not mastery; 5 . Highlight good uses of social media already happening at the institution; 6 . Be aware of the differences between social media and social networking; 7. Build students' awareness of how networks and media work over time and across space and place; 8. Resist the urge to evaluate based on quantitative outcomes; 9. Allow for 'throwaway' accounts; 10. Remind students that nothing is private on the internet; 11. Emphasize accessible technologies.

\section{Conclusions}

Social media's influence on contemporary society is undeniable - more than $1 / 4$ of population is actively using social media, therefore more often discussions arise of social media's use in education, especially for improving teaching and learning experience. In order to employ social media for teaching and learning it is useful to properly prepare for it - get acquainted with social media tools, adjust teaching material to fit the social media, plan how to use social media, prepare social media policy and create social media accounts. There are two main processes in use for social media in teaching and learning: 1. Content creation and sharing; 2. Engagement. Both processes engage teacher and students, therefore a two-way communication is commenced and better relations are established. Due to social media students can better understand the subject, any time, any place give questions, discuss, work in groups over a distance and improve learning experience in other ways. Due to social media, teacher can present the subject with the help of various formats, get feedback about students understanding of subject, share information with all the students independent of their own or students location, they can explain their decisions and to additionally present extra topics or in other way improve teaching experience.

\section{References}

Aula, P. (2010). Social media, reputation risk and ambient publicity management. Strategy \& Leadership, No 38, p. 43-49.

Bexheti, L.A., Ismaili, B.E., \& Cico, B.H. (2014). An Analysis of Social Media Usage in Teaching and Learning: The Case of SEEU. In 2014 International Conference on Circuits, Systems, Signal Processing, Communications and Computers (15. - 17.03.2014). Venice, p. 90-94.

Dabbagh, N., \& Kitsantas, A. (2012). Personal Learning Environments, social media, and self-regulated learning: A natural formula for connecting formal and informal learning. Internet and Higher Education, No 15, p. 3-8.

Danciu, E., \& Grosseck, G. (2011). Social aspects of web 2.0 technologies: teaching or teachers' challenges? In WCES 2011 (03. - 07.02.2011). Elsevier Ltd,, Social and Behavioral Sciences, No 15, p. 3768-3773.

Dear, A.R., \& Potts, L. (2014). Teaching and Learning with Social Media Tools, Cultures, and Best Practices. Programmatic Perspectives, No 6, p. 21-40.

Dijkmans, C., Kerkhof, P., \& Beukeboom, C.J. (2015). A stage to engage: Social media use and corporate reputation. Tourism Management, No 47, p. 58-67.

Kaplan, A. M., \& Haenlein, M. (2010). Users of the world, unite! The challenges and opportunities of social media. Business Horizons, No 53, p. 59-68.

Kapoor, P.S., Jayasimka, K.R., \& Sadh, A. (2013). Brand-related, Consumer to Consumer, Communication via Social Media. IIM Kozhikode Society \& Management Review, No 2, p. 43-59.

Kietzmann, J.H, Hermkens, K., McMarthy, I.P., \& Silvestre B.S. (2011). Social media? Get serious! Understanding the functional building blocks of social media. Business Horizons, No 54, p. 241-251.

Kulakli, A., \& Mahony, S. (2014). Knowledge creation and sharing with Web 2.0 tools for teaching and learning roles in so-called University 2.0. In 10th International Strategic Management Conference (19. - 21.06.2014). Elsevier Ltd., Social and Behavioral Sciences. No 150, p. 648-657.

McCaughey, D., Baumgardner, C., Gaudes, A., LaRochelle, D., Wu, K.J., \& Raichura, T. (2014). Best Practices in Social Media: Utilizing a Value Matrix to Assess Social Media's Impact on Health Care. Social Science Computer Review, No 32, p. 575-589.

McEachern, R.W. (2011). Experiencing a social network in an organizational context: the facebook intership. Business Communication Quarterly, No 74, p. 486-493.

McLeod, D.D.C.S. (2014). Social media marketing and communications strategies for school Superintendents. Journal of Educational Administration, No 52, p. 850-868.

Miloševic, I., Zivkovic, D., Arsic, S., \& Manasijevic, D. (2015). Facebook as virtual classroom - Social networking in learning and teaching among Serbian students. Telematics and Informatics, No 32, p. 576-585.

Moens, M.F., Li, J., \& Chua, T.S. (2014). Mining user generated content. Chapman and Hall/CRC. 
Oberer, B., \& Erkollar, A. (2012). Social media integration in higher education. cross-course google plus integration shown in the example of a master's degree course in management. In CY-ICER 2012 (08. - 10.02.2012).Elsevier Ltd., Social and Behavioral Sciences, No 47, p. 1888-1893.

Parveen, F., Jaafar, N.I., \& Ainin, S. (2015). Social media usage and organizational performance: Reflections of Malaysian social media managers. Telematics and Informatics, No 32, p. 67-78.

Popoiu, M.C., Grosseck, G., \& Holotescu, C. (2012). What do we know about the use of social media in medical education?. In WCES 2012 (02. - 05.02.2012). Elsevier Ltd., Social and Behavioral Sciences, No 46, p. 2262-2266.

Rasiah, R.R.V. (2014). Transformative Higher Education Teaching and Learning: Using Social Media in a Team-Based Learning Environment. In TTLC 2013 (23.11.2013). Elsevier Ltd., Social and Behavioral Sciences, No 123, p. 369-379.

Thomas, M., \& Thomas, H. (2012). Using new social media and Web 2.0 technologies in business school teaching and learning. Journal of Management Development, No 3, p.358-367.

Toplu, D., Yaslioglu, M., \& Erden, N.S. (2014). Corporate Reputation in the Era of Social Media: A Study in Turkish Banking Industry. IUP Journal of Business Strategy, No 11, p. 29-42.

Quirdi, M., Quirdi, A., Segers, J., \& Henderickx, E. (2014). Social Media Conceptualization and Taxonomy. A Lasswellian Framework. Journal of Creative Communications, No 9, p. 107-126.

Verhagen, T., Nauta, A., \& Feldberg, F. (2013). Negative online word-of-mouth: Behavioral indicator or emotional release?. Computers in Human Behavior, No 29, p. 1430-1440.

Voloaca, I.D., Bratu, S., Georgescu, M., Ghencea, F.L., \& Voicu, A. (2011). The importance of creativity in advertising, digital technology, and social networking. Economics, Management, and Financial Markets Volume, No 6, p. 449-458.

Wagner, R. (2011). Social Media Tools for Teaching and Learning. Atheletic Training Education Journal, No 6, p. 51-52.

Zolkos, R. (2012). Rules of engagement: How social media alters reputation risk. Business Insurance, No 46, p. 01-01. 